\title{
РАЗРАБОТКА И ИССЛЕДОВАНИЕ ОПТИЧЕСКИХ ТЕРМОСТАБИЛЬНЫХ КОМПАУНДОВ МФ ТЭ-1, ТЭ-2, ТЭ-3 \\ СИЛИКОНОВЫЕ ЗАЛИВОЧНЫЕ КОМПАУНДЫ, НАРАБОТКА, ТЕРМОЦИКЛИРОВАНИЕ.
}

\author{
Павлова Александра Анатольевна \\ Томский Государственный Университет \\ Систем Управления и Радиоэлектроники (ТУСУР), \\ магистр. \\ Санько Сергей Александрович \\ Научно-исследовательский институт полупроводниковых приборов (НИИПП), \\ инженер-конструктор. \\ Хотненок Юрий Анатольевич \\ Научно-исследовательский институт полупроводниковых приборов (НИИПП), \\ инженер-конструктор I категории.
}

\section{SILICONE CASTING COMPOUNDS, OPERATING TIME, THERMOCYCLING.}

\author{
Pavlova Alexandra Anatolievna \\ Tomsk State University of Control Systems and Radio electronics (TUSUR), \\ master degree. \\ Sanko Sergey Alexandrovich \\ Research Institute of Semiconductor Devices, \\ design engineer. \\ Khotnenok Yuri Anatolievich \\ Research Institute of Semiconductor Devices, \\ design engineer of the 1st category.
}

\footnotetext{
Аннотация. Целью работы является получение оптически прозрачного и термостабильного компаунда в диапазоне температур от минус $65^{\circ} \mathrm{C}$ до $85^{\circ} \mathrm{C}$ для применения в устройствах микроэлектроники.

Основными задачами является разработка компаундов, удовлетворяющих требованиям, проведение их испытаний и исследований, а также анализ полученных данных.

Основным практическим применением разработанных компаундов является применение в качестве защитных компаундов для устройств микроэлектроники.

The work aim is optically transparent and thermostable compound obtaining in the temperature range from minus 65 ${ }^{\circ} \mathrm{C}$ to $85^{\circ} \mathrm{C}$ for use in microelectronic devices.

The main tasks are the development of compounds that meet the requirements, their testing and research, and the analysis of the data.

The main practical application of the developed compounds is as protective compounds for microelectronic devices.

Введение

Долгосрочная, надежная защита чувствительных приборов приобретает всё большую значимость для современной электроники. Заливочные компаунды на основе силикона обеспечивают надежную диэлектрическую изоляцию, амортизируют механические напряжения и вибрации, выступают как барьер против загрязнений из окружающей среды, сохраняя свойства в широком диапазоне температур и влажности.

Заливочные компаунды - это группа защитных материалов, используемых в качестве изоляторов электроники от действия неблагоприятных факторов. С помощью компаундов проводится полная герметизация электроники, - такая защита обеспечивает отличные рабочие параметры даже в условиях экстремальной окружающей среды [1].

С помощью силиконовых компаундов можно заполнять различные полости без риска появления конденсата и нежелательной влаги на поверхности обработанных изделий. Для продукции с установленными внутри светодиодами существуют специализированные оптически прозрачные составы [2].

Основные преимущества:

- оптимальный вариант для хрупкой электроники;

- защита от загрязнения, поступающего из внешней среды;

- обеспечение свойств надежного диэлектрика;

- амортизация механического напряжения;

- легкое и быстрое нанесение;

- $\quad$ подавление вибрации.
} 
Помимо сохранения своих физических и электрических свойств в широком диапазоне рабочих условий, силиконы устойчивы к разрушению под воздействием озона и ультрафиолета и обладают хорошей химической стабильностью [3].

В настоящее время для заливки светодиодов (СИД) на предприятии используется силиконовый компаунд фирмы DOW CORNING OE6636, имеющий высокий показатель преломления $\mathrm{n}=1,53$, а соответственно, хороший световыход. Данный компаунд удовлетворяет требованиям по реологическим показателям (текучий, хорошо выходят пузыри), хорошо защищает серебро от потемнения, удовлетворительная твердость, но не удовлетворяет по критерию стойкости при термоциклировании (выдерживает температуру до минус $40^{\circ} \mathrm{C}$, но при понижении до минус $65^{\circ} \mathrm{C}$ компаунд отходит от стенок корпуса диода).

В связи с проблемой использования компаунда DOW CORNING OE6636, был выбран и опробован аналог данного продукта, - силиконовый компаунд СИЭЛ 159-254 М3 (осветлённый). Выбранный компаунд характеризуется стойкостью к низкой температуре (до минус $80^{\circ} \mathrm{C}$ ), хорошей прозрачностью и адгезией к керамике. Главными его недостатками являются низкий показатель преломления ( $\mathrm{n}=1,41$, что составляет на $10 \%$ меньше, чем у ОЕ6636) и мягкость (легко повреждается, липкий). Также при использовании СИЭЛ 159-254 М3, серебро под ним быстро темнеет при наработке и при испытаниях на серу. С целью устранения указанных недостатков, были разработаны компаунды на основе СИЭЛ 159-254 М3: МФ-ТЭ-1, МФ-ТЭ-2 и МФ-ТЭ-3.

\section{Данные о методике исследования}

Долговременные испытания на наработку проходят при мощности СИД $\mathrm{P}=1$ Вт (соответственно $\mathrm{I}_{\text {пр }}=350 \mathrm{MA}$, $\left.\mathrm{U}_{\text {пр }}=3 \mathrm{~B}\right)$ и окружающей температуре $\mathrm{T}_{\text {окр }}=85^{\circ} \mathrm{C}$ в соответствии с ГОСТ $\mathrm{P}$ 27.607-2013. Как оказалось, существенное влияние на долговременную работоспособность приборов оказывают материал корпуса (пластмасса или керамика) и крепление кристалла в корпусе: либо на эпоксидный клей DIEMAT, либо на припойную пасту - бессвинцовая паста $\mathrm{SACm}\left(88,5 \% \mathrm{InCu}, \mathrm{T}_{\text {пл }}=230^{\circ} \mathrm{C}\right)$.

\section{Экспериментальная часть}

Первым разработанным компаундом был компаунд МФ-ТЭ-1 (А вязкая: Б жидкая $=1: 1,150$ ॰C/1час), по консистенции более вязкий, чем ОЕ6636, подобен ему по твёрдости. По световыходу оба компаунда дают одинаковые результаты, что говорит о хорошей прозрачности и высоком показателе преломления. В ходе работы исследуются три из четырех возможных вариантов (пластмассовый и керамический корпуса, клей DIEMAT и припойная паста $\mathrm{SACm})$. На рисунке 1 приведены характеристики светового потока СИД при наработке с компаундом МФ-ТЭ-1.
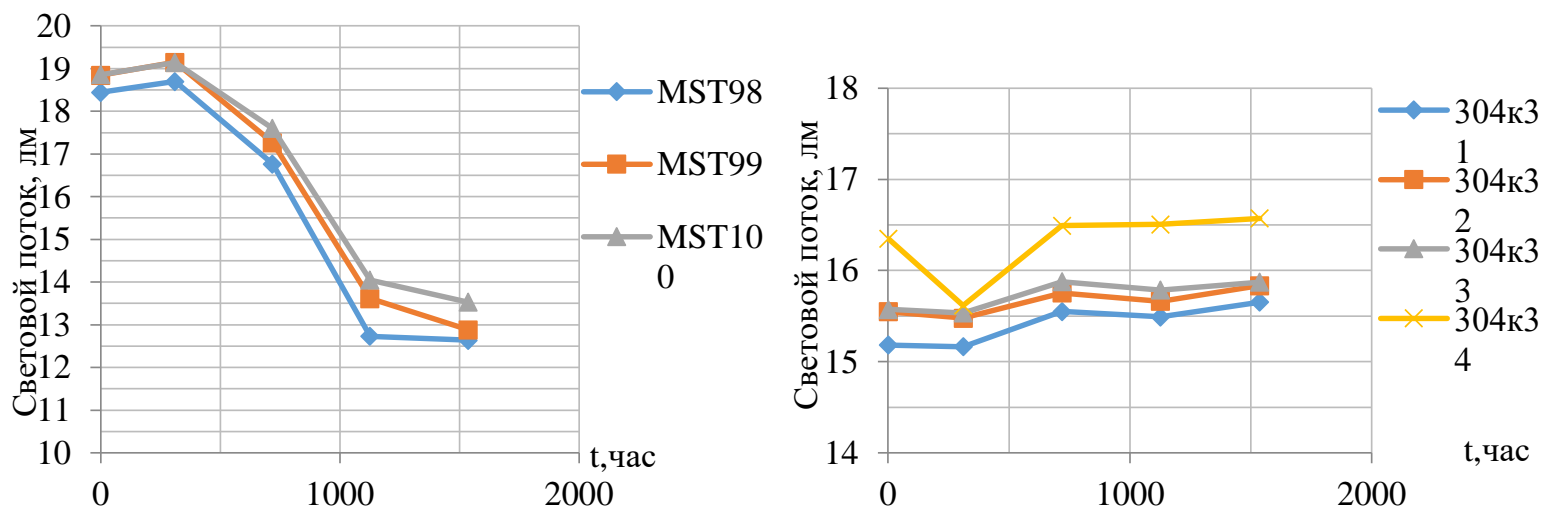

a) б)

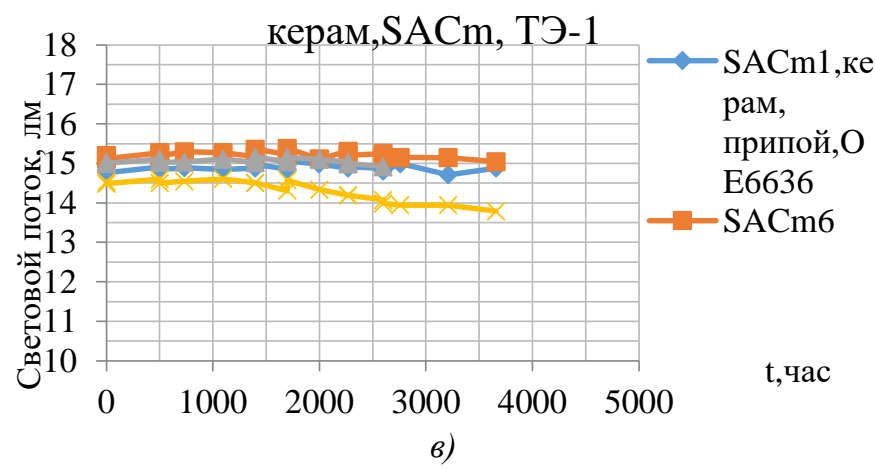

Рисунок 1 - Характеристики светового потока СИД при наработке с компанудом МФ-ТЭ-1: апластмассовый корпус, клей DIEMAT; б - керамический корпус, клей DIEMAT; в - керамический корпус, припойная паста SACm 
На пластмассовом корпусе с клеем уже при 719 часах наработки клей под кристаллом почернел. При 3658 часах наработки на керамических корпусах с клеем и припойной пастой серебро, кристалл и стенки корпуса не имеют видимых изменений, а световой поток стабилен.

Далее был разработан и исследован компаунд МФ-ТЭ-2, который в сравнении с ТЭ-1 характеризуется большей жесткостью, темнее, а световыход меньше на 5-15\%.

В ходе работы исследовались пластмассовые и керамические корпуса с клеем DIEMAT. При наработке (рисунок 2) на пластмассовых корпусах сначала происходит подъём (500 час), затем световыход падает ниже начального состояния (1500 час), после чего стабилизируется на одном уровне. На керамических корпусах световыход повышается при наработке со 1000 часов, затем стабилизируется.

По внешнему виду на пластмассовом корпусе (№304L) образуются чёрные пятна на клее под кристаллом, темнеют стенки корпуса, и происходит небольшое окисление серебра по периметру. На керамическом корпусе (№410э) кристалл и серебро видимых изменений не имеют.
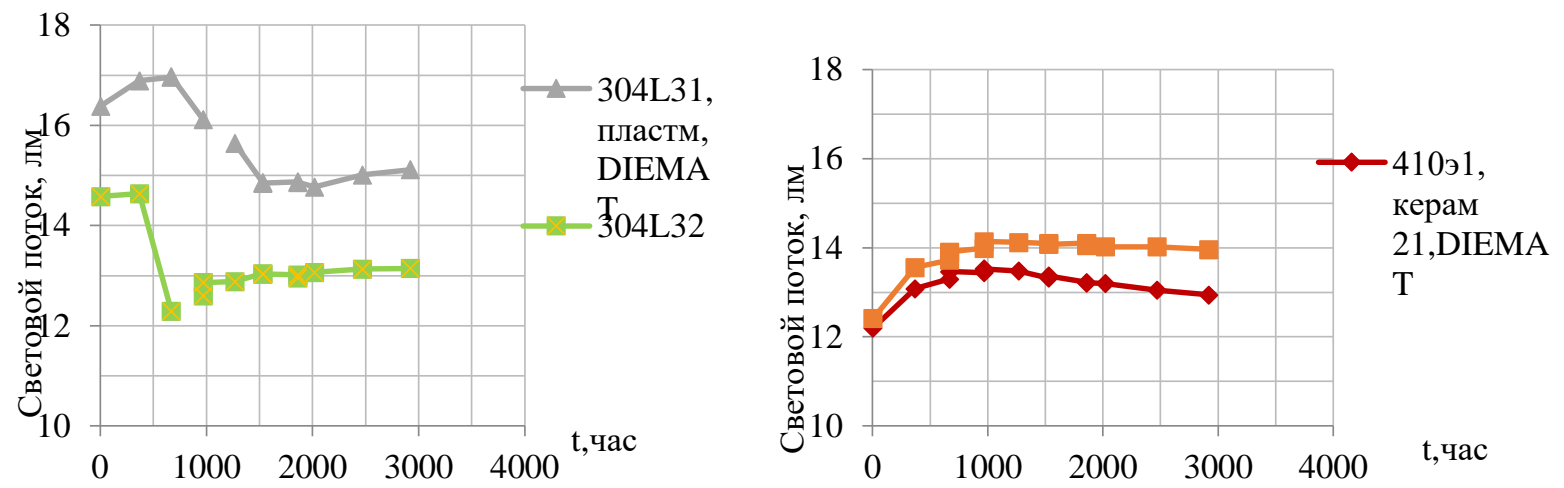

a) б)

Рисунок 2 - Наработка СИД в керамических и пластмассовых корпусах с компаундом ТЭ-2: а - пластмассовый корпус, клей DIEMAT; б - керамический корпус, DIEMAT

Далее был разработан и исследован компаунд МФ-ТЭ-3 (А:Б=1:2, 150С/1час). При исследовании на наработку СИД в пластмассовых корпусах с клеем DIEMAT, на серебре, клее и стенках корпуса появляется коричневый налёт, а световой поток резко падает на 3-6\% (рисунок 3).

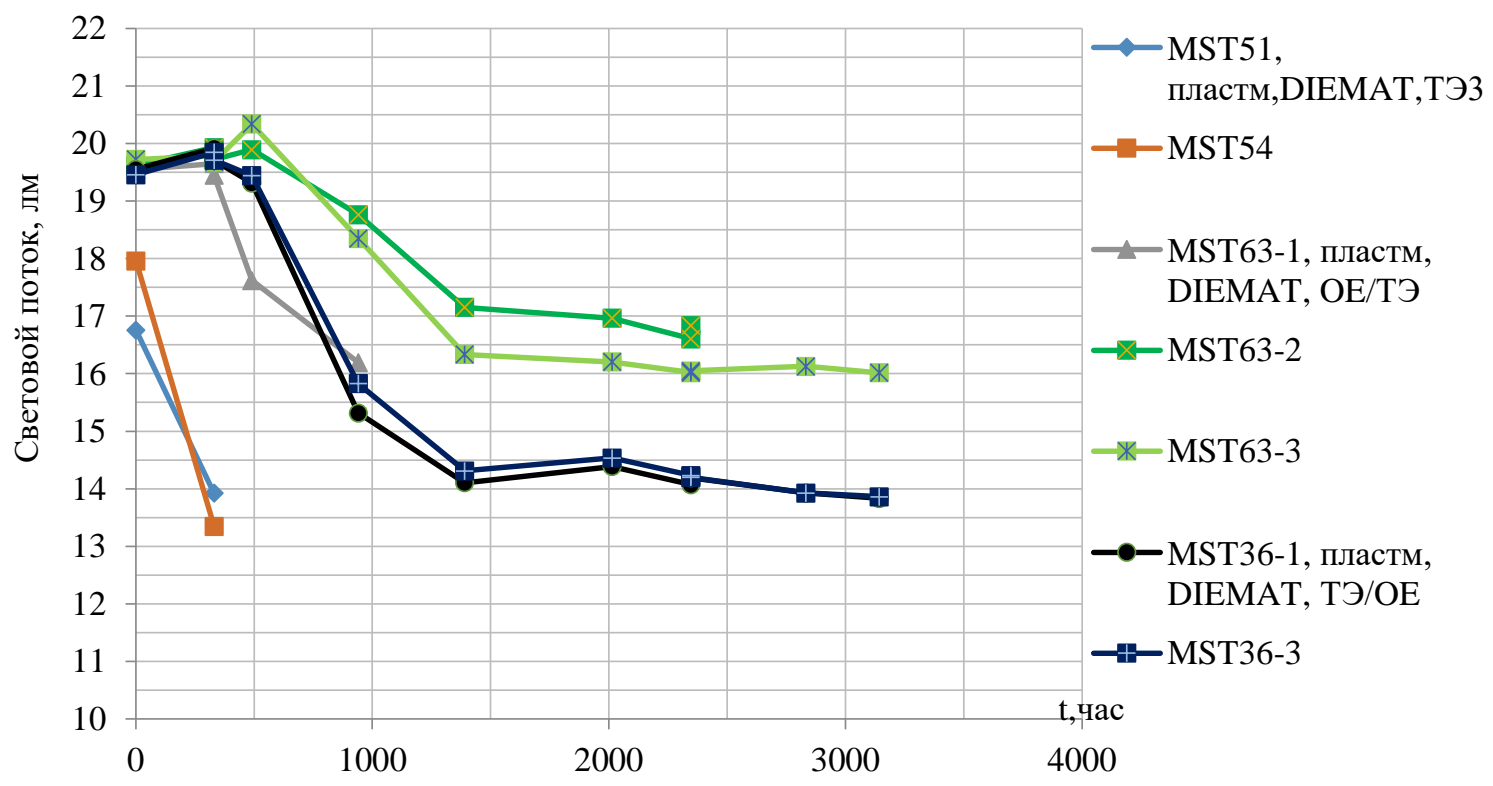

Рисунок 3 - Наработка СИД в пластмассовом корпусе с компаундом ТЭ-3 (№MST51,54) и смесью ТЭ-3 с OE6636 (№MST63-1,2,3 и №MST36-2,3) в пластмассовых корпусах с клеем DIEMAT 
С целью определения компонент ТЭ-3, ответственных за потемнение, были сделаны смеси А(ТЭ-3): Б(ОЕ6636) и A(OE6636): Б(ТЭ-3) - соответственно диоды MST36 и MST63 в пластмассовых корпусах.

Результаты исследования, следующие: на СИД №MST36-1 (ТЭ-3: ОЕ6636, 3143час) видны чёрные клей и серебро, коричневый налёт по внутренней части стенок корпуса. На СИД №MST63-3 (OE6636: ТЭ-3, 3143час) внешний вид клея не изменился, серебро потемнело, появился коричневый налёт на внутренней части стенок корпуса.

Таким образом, в ходе проведения исследований на наработку, было определено, что для компаундов СИЭЛ в пластмассовом корпусе с клеем характерно следующее изменение светового потока: подъём, спад на 30-20\%, стабилизация. В таблице 1 представлены результаты исследований на наработку.

Таблица 1

Световыход при наработке на СИД в пластмассовых и керамических корпусах с разными компаундами

\begin{tabular}{|c|c|c|c|c|c|}
\hline \multirow[b]{2}{*}{ Характеристика } & \multicolumn{5}{|c|}{ Материал } \\
\hline & $\begin{array}{c}\text { СИЭЛ 159- } \\
254 \mathrm{M} 3\end{array}$ & СИЭЛ МФ-ТЭ-1 & СИЭЛ МФ-ТЭ-2 & СИЭЛ МФ-ТЭ-3 & OE6636 \\
\hline $\begin{array}{c}\text { Световыход по } \\
\text { отношению к } \\
\text { компаунду ОЕ6636, } \\
\text { до испытаний, \% }\end{array}$ & 90 & 100 & 94 & 100 & 100 \\
\hline $\begin{array}{c}\text { Наработка } \\
\text { Iпр=350мA, T=85C. } \\
\text { Синие СД, } \\
\text { керамический } \\
\text { корпус }\end{array}$ & - & $\begin{array}{c}100 \% / 3210 ч \\
\text { чистые } \mathrm{Ag}, \\
\text { корпус }\end{array}$ & $\begin{array}{c}106 \% / 2470 \text { ч } \\
\text { чистые Ag, } \\
\text { корпус }\end{array}$ & - & $\begin{array}{c}102 \% / 8000 ч \\
\text { чистые } \mathrm{Ag} \text { и } \\
\text { корпус }\end{array}$ \\
\hline $\begin{array}{c}\text { Пластмассовый } \\
\text { корпус }\end{array}$ & $\begin{array}{l}\text { тёмный клей } \\
\text { и Аg (начало } \\
\text { окисл. } \mathrm{Ag} \\
\text { 2500ч) }\end{array}$ & - & $\begin{array}{c}\text { 92\% /2470ч чуть } \\
\text { коррозия Аg, на } \\
\text { клее чёрный, на } \\
\text { пластм. корпусе } \\
\text { коричневый налёт }\end{array}$ & $\begin{array}{c}\text { 79\% /330ч } \\
\text { коричневый налёт } \\
\text { на Ag и стенках } \\
\text { корпуса }\end{array}$ & $\begin{array}{c}102 \% / 8000 \text { ч } \\
\text { чистый } \mathrm{Ag}\end{array}$ \\
\hline Световыход - & $\begin{array}{r}\text { тношение св } \\
\% / \text { час - }\end{array}$ & ого потока СИ) & $\begin{array}{l}\text { анным компаундом } \\
\text { вого потока / время }\end{array}$ & СИД с компаундо & 6636. \\
\hline
\end{tabular}

Методика исследования приборов на термоциклирование соответствует ГОСТ Р 51368-99.

При термоциклировании компаунда МФ-ТЭ-1 (10 циклов (минус $65^{\circ} \mathrm{C} / 30$ мин $-85^{\circ} \mathrm{C} / 30$ мин)) на СИД в пластмассовом корпусе из пяти образцов на четырёх произошло отслоение компаунда от корпуса и произошло четыре обрыва золотой проволоки (в то же время 5 образцов на ОЕ6636 успешно прошли испытания). На керамическом корпусе на одном из двух образцов произошло отслоение компаунда от стенок корпуса.

На испытания по термоциклированию компаунда МФ-ТЭ-2 были представлены как готовые СИД (корпус, наклеенный и распаянный золотой проволокой кристалл), так и пустые корпуса без кристалла:

- 5 шт. СИД №304L в пластмассовом корпусе smd5050-33;

- 5 шт. СИД №410э в керамическом корпусе L035035-21;

- 10 шт. пластмассовых корпусов smd5050-ц;

$-1$

1 Все диоды и корпуса были залиты компаундом МФ-ТЭ-2 (соотношение $\mathrm{A} / \mathrm{Б}=1 / 2$, сушка $150^{\circ} \mathrm{C} / 2$ ). Проведено 10 термоциклов (минус $65^{\circ} \mathrm{C} / 30$ мин $-100^{\circ} \mathrm{C} / 30$ мин).

ш Результаты термоциклирования:

т После термоциклов вольт-амперные характеристики на пластмассовых диодах №304L не изменились, а на керамических №410Э на двух диодах из пяти - обрыв.

Внешний вид больших пластмассовых корпусов 5*5мм smd5050-ц удовлетворяет по всем критериям, на СИД в подобных корпусах smd5050-33 на двух из пяти диодов произошло отслоение компаунда от стенок корпуса.

e На больших керамических корпусах 5*5мм L050050-06 на десяти из одиннадцати произошло растрескивание ұ отслоение компаунда от корпуса, а на всех диодах в керамических корпусах $3,5 * 3,5$ мм произошло отслоение қомпаунда от корпуса.

м Таким образом, после проведения десяти термоциклов (минус $65^{\circ} \mathrm{C}-100^{\circ} \mathrm{C}$ ) на пластмассовых корпусах (без қристаллов) внешний вид остался неизменным, а на диодах с кристаллами произошло частичное отслоение қомпаунда от стенок корпуса. У керамических корпусов неудовлетворительный внешний вид, обрывы на ВАХ. 
Трещинки по краям появляются от повышенной хрупкости при сильном затвердении компаунда на морозе (коэффициент термического расширения компаунда порядка 150-200ppm, а у керамики 5-10ppm).

В сравнении с компаундом ТЭ-1, на термоциклах компаунд ТЭ-2 обладает лучшими характеристиками на пластмассовых корпусах, на керамических же ни один из компаундов не удовлетворяет критериям.

С целью улучшения стойкости к термоциклам были проведены работы с компаундами МФ-ТЭ-2-2 и МФ-ТЭ3. В таблице 2 приведены результаты исследований компаундов при термоциклировании.

Таблица 2

Результаты исследований при термоциклировании (минус $65^{\circ} \mathrm{C} / 30 \mathrm{Mин}-85^{\circ} \mathrm{C} / 30$ мин)

\begin{tabular}{|c|c|c|c|c|c|c|c|c|c|c|c|c|}
\hline \multicolumn{13}{|c|}{ Материал } \\
\hline & $\begin{array}{c}\text { кол } \\
\text {-во }\end{array}$ & $\begin{array}{c}\text { СИЭ } \\
\text { Л } \\
159- \\
254 \\
\text { М3 }\end{array}$ & $\begin{array}{c}\text { кол } \\
\text {-во }\end{array}$ & $\begin{array}{l}\text { СИЭ } \\
\text { Л } \\
\text { МФ- } \\
\text { ТЭ-1 }\end{array}$ & $\begin{array}{c}\text { кол } \\
\text {-во }\end{array}$ & $\begin{array}{c}\text { СИЭЛ МФ- } \\
\text { ТЭ-2 }\end{array}$ & $\begin{array}{l}\text { кол } \\
\text {-во }\end{array}$ & $\begin{array}{l}\text { СИЭЛ } \\
\text { МФ- } \\
\text { ТЭ-2-2 }\end{array}$ & $\begin{array}{c}\text { кол } \\
\text {-во }\end{array}$ & $\begin{array}{l}\text { СИЭ } \\
\text { Л } \\
\text { МФ- } \\
\text { ТЭ-3 }\end{array}$ & $\begin{array}{l}\text { кол } \\
\text {-во }\end{array}$ & $\begin{array}{c}\text { OE663 } \\
6\end{array}$ \\
\hline $\begin{array}{c}\text { СД №304L } \\
\text { пластмассовы } \\
\text { й корпус } \\
\text { smd5050-33 } \\
\end{array}$ & 10 & Xоp & 10 & $\begin{array}{c}\text { 7- } \\
\text { OBY, } \\
6-X X\end{array}$ & 5 & 2-ОБ & - & - & - & - & 5 & 5 xop \\
\hline $\begin{array}{c}\text { пластмассовы } \\
\text { й корпус } \\
\text { smd5050-ц }\end{array}$ & 10 & Xор & - & - & 18 & $\begin{array}{c}3- \\
\text { потрескалис } \\
\text { ь и ОВЧ }\end{array}$ & - & - & - & - & - & - \\
\hline $\begin{array}{c}\text { керамический } \\
\text { корпус } \\
\text { L050050-06 }\end{array}$ & 10 & Xоp & 2 & $\begin{array}{c}1- \\
\text { OBY }\end{array}$ & 25 & $\begin{array}{c}15- \\
\text { потрескалис } \\
\text { ь и ОВЧ } \\
\end{array}$ & 12 & $\begin{array}{c}2- \\
\text { xop,10 } \\
- \text { OBY } \\
\end{array}$ & - & - & 14 & $\begin{array}{c}14- \\
\text { OBY }\end{array}$ \\
\hline $\begin{array}{c}\text { керамический } \\
\text { корпус } \\
\text { L050050-06 с } \\
\text { крист } \\
\end{array}$ & - & - & - & - & - & - & 7 & 7-OBЧ & 7 & $\begin{array}{c}\text { 3-xop, } \\
4- \\
\text { OBप }\end{array}$ & 6 & 7-OBप \\
\hline $\begin{array}{c}\text { керамический } \\
\text { корпус } \\
\text { L050050-06 } \\
\text { без крист, } \\
\text { подслой } \\
\text { СИЭЛ 159- } \\
254 \\
\end{array}$ & - & - & - & - & - & - & 19 & $\begin{array}{l}\text { 4-ОБ, } \\
\text { 19-ОВ }\end{array}$ & - & - & - & - \\
\hline $\begin{array}{c}\text { керамический } \\
\text { корпус } \\
\text { L050050-06 } \\
\text { без крист, } \\
\text { подслой } \\
\text { СИЭЛ 159- } \\
254 \text { (сушился } \\
\text { верх ногами) } \\
\end{array}$ & - & - & - & - & - & - & 14 & $\begin{array}{l}\text { 2-xop, } \\
\text { 10-OB }\end{array}$ & 14 & $\begin{array}{l}\text { 5-xop, } \\
\text { 7-OB }\end{array}$ & - & - \\
\hline $\begin{array}{c}\text { СД №410 } \\
\text { керамический } \\
\text { корпус } \\
\text { L035035-06 }\end{array}$ & 10 & Xор & - & - & 5 & $\begin{array}{c}\text { 5-OBप, 2- } \\
\text { XX }\end{array}$ & - & - & - & - & - & - \\
\hline $\begin{array}{c}\text { керамический } \\
\text { корпус } \\
\text { L035035-21 }\end{array}$ & 10 & Хор & - & - & 4 & $\begin{array}{c}2- \\
\text { потрескалис } \\
\text { в и ОВЧ }\end{array}$ & - & - & - & - & - & - \\
\hline & & $\begin{array}{l}\text { шла I } \\
\text { В - } 0\end{array}$ & 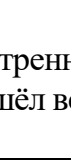 & $\begin{array}{l}\mathrm{XX}- \\
\text { часть } \\
\text { I кол } \\
\mathrm{p}-\text { - вH } \\
\end{array}$ & Іний & $\begin{array}{l}\text { ход (обрыв н } \\
\text { нд отходит от } \\
\text { ходит от верх } \\
\text { д и ВАХ не и }\end{array}$ & & $\begin{array}{l}\text { нней ча } \\
\text { и стенс } \\
\text { сь. }\end{array}$ & орп & к корп & & \\
\hline
\end{tabular}

Таким образом, ни один компаунд, кроме СИЭЛ159-254, не выдерживает термоциклы в режиме 10 циклов по 30 минут в диапазоне температур от минус $65^{\circ} \mathrm{C}$ до $85^{\circ} \mathrm{C}$. 
С целью повышения стойкости СИД к термоциклам был введён мягкий подслой. Сначала в качестве подслоя использовался СИЭЛ 159-254, затем желеобразный СИЭЛ ТМ. Как видно из таблицы 3, подслой явно улучшает характеристики образцов. На керамических корпусах уходит брак ОВЧ (компаунд отходит от внутренней части стенок корпуса), но появляется ОВ (компаунд отходит от верхней части стенок корпуса) - видимо, при сушке подслоя, компаунд стекает с верхней части стенок корпуса. Было предложено сушить диоды вверх дном, что дало хорошие результаты, но при термоциклах образуется канавка по внешним стенкам корпуса (ОК).

Таблица 3

Испытания СИД с подслоем

\begin{tabular}{|c|c|c|c|}
\hline & Пластмассовый корпус & $\begin{array}{c}\text { Керамика Elit Fine L050050- } \\
\text { 06 }\end{array}$ & $\begin{array}{c}\text { Керамика SemiLeds } \\
\text { МСН L050050-06 }\end{array}$ \\
\hline Компаунд ТЭ-2-2 & - & из 12: 2-хор 10-ОВЧ & \\
\hline $\begin{array}{c}\text { Подслой СИЭЛ 159-254 М3, компаунд ТЭ- } \\
2-2\end{array}$ & - & $\begin{array}{c}\text { из 9: 4-ОВЧ 9-ОК. Вверх } \\
\text { дном из 14: 2-хор, 10-ОК }\end{array}$ & из 10: 10-ОК \\
\hline Компаунд ТЭ-3 & - & из 7: 3-хор, 4-ОВЧ & - \\
\hline $\begin{array}{c}\text { Подслой СИЭЛ 159-254 М3, компаунд ТЭ- } \\
3\end{array}$ & - & из 14: 5-хор, 7-ОК & - \\
\hline $\begin{array}{c}\text { Подслой СИЭЛ ТМ, компаунд ТЭ-3 } \\
\text { Вверх дном из 9: 9 хор }\end{array}$ & - & - \\
\hline Компаунд ОЕ6636 & - & из 20: 20-ОВЧ & - \\
\hline
\end{tabular}

Для более качественной проверки были проведено 100 термоциклов на 15 образцах (пластмассовый корпус / подслой СИЭЛ ТМ / OЕ6636). Сначала 40 циклов с повышением верхнего предела температуры на каждых 10 циклах от $\left(+85^{\circ} \mathrm{C}-\right.$ минус $\left.60^{\circ} \mathrm{C}\right)$ до $\left(+175^{\circ} \mathrm{C}-\right.$ минус $\left.60^{\circ} \mathrm{C}\right)$, затем 60 циклов с понижением нижнего предела от $\left(+85^{\circ} \mathrm{C}\right.$ - минус $\left.60^{\circ} \mathrm{C}\right)$ до $\left(+85^{\circ} \mathrm{C}-\right.$ минус $\left.80^{\circ} \mathrm{C}\right)$. По внешнему виду все образцы успешно прошли испытания, но на восьми образцах из пятнадцати зафиксирован холостой ход (видимо, обрыв золотой проволоки). Отмечается падение световой мощности при 10 термоциклах $\left(+175^{\circ} \mathrm{C}-\right.$ минус $\left.60^{\circ} \mathrm{C}\right)$ на $10 \%$, что свидетельствует об ухудшении свойств СИЭЛ ТМ при нагреве свыше $150^{\circ} \mathrm{C}$.

Таким образом, перспективным выглядит подслой СИЭЛ ТМ с компаундом ТЭ-3, но неосветлённый компаунд ТЭ-3 быстро деградирует при наработке (таблица 4).

Таблица 4

Световыход при наработке на СИД в пластмассовых и керамических корпусах с разными компаундами

\begin{tabular}{|c|c|c|c|c|c|c|}
\hline \multirow[t]{2}{*}{ Характеристика } & \multicolumn{6}{|c|}{ Материал } \\
\hline & $\begin{array}{c}\text { СИЭ } \\
\text { Л } \\
159- \\
254 \\
\text { М3 }\end{array}$ & $\begin{array}{c}\text { СИЭ } \\
\text { Л } \\
\text { МФ- } \\
\text { ТЭ-1 }\end{array}$ & $\begin{array}{c}\text { СИЭЛ } \\
\text { МФ-ТЭ-2 }\end{array}$ & $\begin{array}{c}\text { СИЭ } \\
\text { Л } \\
\text { МФ- } \\
\text { ТЭ- } \\
2-2 \\
\end{array}$ & $\begin{array}{c}\text { СИЭЛ } \\
\text { МФ-ТЭ-3 }\end{array}$ & $\begin{array}{l}\text { OE66 } \\
36\end{array}$ \\
\hline $\begin{array}{c}\text { Световыход по отношению к компаунду ОЕ6636, до } \\
\text { испытаний, \% }\end{array}$ & 90 & 100 & 94 & 97 & 100 & 100 \\
\hline $\begin{array}{c}\text { Наработка Іпр=350мА, Т=85С. Синие СД, } \\
\text { Керамический корпус }\end{array}$ & - & $\begin{array}{c}100 \% \\
13210 \\
\text { ч } \\
\text { чист } \\
\text { ые } \\
\mathrm{Ag}, \\
\text { корпу } \\
\text { с }\end{array}$ & $\begin{array}{c}106 \% \\
/ 2470 \text { ч } \\
\text { чистые } \\
\mathrm{Ag}, \\
\text { корпус }\end{array}$ & - & - & $\begin{array}{c}102 \% / \\
8000 \text { } \\
\text { чисты } \\
\text { e Ag и } \\
\text { корпу } \\
\text { с }\end{array}$ \\
\hline Пластмассовый корпус & $85 \%$ & & $92 \%$ & & $79 \% / 330 ч$ & $102 \%$ \\
\hline
\end{tabular}




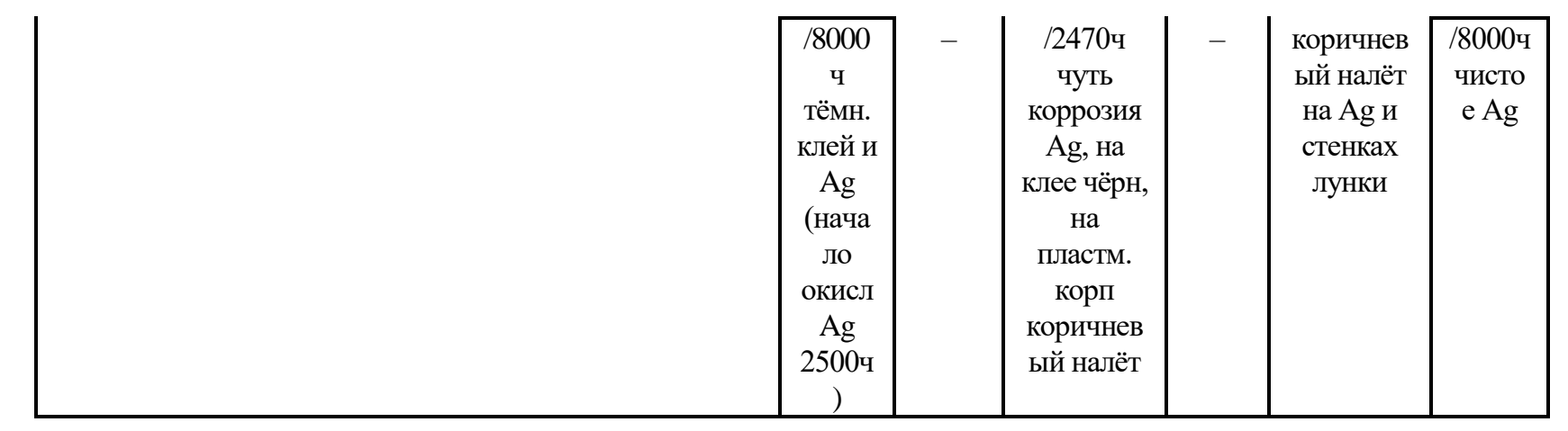

\section{Выводы}

При наработке СИД в пластмассовых корпусах с клеем DIEMAT чернеет клей под кристаллом, темнеют стенки корпуса, чернеет серебро. При использовании компаунда DOW CORNING OE6636 в пластмассовых корпусах внешний вид СИД не изменяется. В керамических корпусах и с клеем DIEMAT, и с безоловянным припоем SACm внешний вид светодиодов не меняется. Световой поток СИД в пластмассовых корпусах с клеем DIEMAT падает на 10-20\% в течение первой тысячи часов, после чего стабилизируется. В керамических корпусах и с клеем, и с припоем световой поток стабилен.

На основании проведенных исследований можно сделать вывод о стабильности заливочного компаунда СИЭЛ 159-254, при испытании на термоциклирование 10 циклов (минус $65^{\circ} \mathrm{C}-85^{\circ} \mathrm{C}$ ), он сохраняет свои свойства и не приводит к выходу из строя приборов. Однако, введение подслоя СИЭЛ ТМ к компаунду МФ ТЭ-3 повышает стойкость к термоциклированию и хороший световыход, обеспечивает удовлетворительно твёрдую поверхность. Но на данный момент заливочный компаунд ТЭ-3 характеризуется неудовлетворительной светостойкостью при наработке.

\section{Список литературы}

1. Силиконовые заливочные компаунды для печатных плат. Date Views 10.06.2021/ostecmaterials.ru/materials/dlya-sborki-elektron/silikonovye zalivochnye - kompau.php.

2. Илларионов, В.Н. and С.Р. Нанушьян, 2001. Силиконовые компаунды СИЭЛ. Экономика и производство, ришин, М.В., Т.И. Зелякова and С.О. Рубан, 2020. РЕЗУЛЬТАТЫ ИССЛЕДОВАНИЯ ВЛАГОЗАЩИТНЫХ СВОЙСТВ КОМПАУНДОВ МАРОК СИЭЛ 159-167, СИЭЛ 159-190, СИЭЛ 159-254, СИЭЛ 159-256. ТРУДЫ $\mathrm{M}$

$\mathrm{E}$

Ж

Д

y

$\mathrm{H}$

A

P

$\mathrm{O}$

Д

$\mathrm{H}$

O

$\Gamma$

O

C

И

M

$\Pi$

O 